\title{
Land rehabilitation in arid Gobi Desert environment using native plant species
}

\author{
A Balt Oyu Tolgoi LLC, Mongolia \\ E Batdelger National University of Mongolia, Mongolia \\ B Odsuren National University of Mongolia, Mongolia \\ U Sainbileg National University of Mongolia, Mongolia \\ A Enkhtuya Oyu Tolgoi LLC, Mongolia \\ JD Hamilton Oyu Tolgoi LLC, Mongolia \\ B Bazartseren National University of Mongolia, Mongolia
}

\begin{abstract}
The ability to rehabilitate disturbed lands and restore ecosystem processes is of great importance for the mine closure process as functional ecosystems maintain long-term biodiversity and ecosystem service values. The Oyu Tolgoi (OT) Mine, located in Umnugobi Aimag, southern Mongolia, is known for its production of copper (450,000 tonnes per year), making it the largest financial undertaking in Mongolia's history. Despite this, the OT mine has several challenges to overcome in order to develop processes that will assist in the rehabilitation and restoration of areas disturbed by mining development activities. The first challenge was an early commitment to using only native species, which relates to the second challenge caused by the harsh desert climate where the mine is located in. The unprecedented decision to use only native species was a challenge as little research had previously been done on how to grow native Gobi Desert plant species and use them in rehabilitation efforts. This knowledge gap led to the creation of the OT Native Plant Propagation Center (NPPC) in Khanbogd Soum, Mongolia to conduct research on the collection of seeds, propagation of plants, and preparing seeds and saplings for restoration work. By starting rehabilitation programs early (during the construction stage), OT has had time to develop and test rehabilitation methods and begin to rehabilitate areas to allow more time for plants to establish and grow. While OT is still in the construction phase, it has already gained 10 years of experience in growing native Gobi plant species and rehabilitating disturbed areas through the drill seeding and hydroseeding as well sapling planting method.

In this study, the monitoring survey was conducted in 2017-2018 by comparing the three rehabilitated areas in 2013 using the above three methods and the adjacent undisturbed areas. Vegetation cover, species richness and biomass were measured at $30 \mathrm{~m} \times 30 \mathrm{~m}$ plot which was established in each study site and similarity was analyzed.

Preliminary results of comparing biologically rehabilitated areas to the control plots showed that the sapling planted area has the greatest similarity (75\%) and no difference in vegetation cover and biomass $(t=-0.88$, $p=0.40 ; t=-0.22, p=0.83$ ) with the control. In contrast, the similarity of the hydroseeded area was $45.5 \%$, while the drill seeded area was the least similar to the control area (0\%). This suggests that the sapling planting method was the most successful rehabilitation method. However, the study will be continued to include more rehabilitated areas and allow more time for vegetation recovery in rehabilitated areas.
\end{abstract}

Keywords: native plants, Gobi desert, rehabilitation, plant propagation 


\section{Introduction}

Central Asia hosts some of the largest steppe and semi-desert areas in the world (Wesche et al. 2012) and detailed knowledge on their ecological conditions is of high interest in terms of basic research, but also for applied aspects including land use and conservation. In arid and semi-arid steppe, roots of shrubs and woody plants grow deep into the ground resulting in soil erosion decrease, thereby a habitat can be maintained to support promote biological diversity. Shrubs and trees may also increase nutrients for other plants' growing environments, reduce stress due to lack of moisture, and improve soil physical properties (Belsky et al. 1989; Tiedemann and Klemmedson 1973, 2004).

Desertification and land degradation are major threats for ecological, economic and social conditions in most drylands of the world. Inappropriate land-use practices, over-exploitation (mining, rangeland) of natural resources and climate change are major factors, which lead to desertification (Veste et al. 2001). Mining activities in Mongolia have intensified over the past 30 years, with 2,610 valid mineral licenses covering 6,141.7 thousand hectares in Mongolia, of which 160 licenses covering 916.2 thousand hectares belong to the territory of Umnugovi aimag (Mineral Resources and Petroleum Authority of Mongolia, 2021). An inventory was conducted in areas that were disturbed or left unrehabilitated due to mining operations by The Ministry of Nature, Environment and Tourism in 2017-2018. According to the census, there were $27,405.46$ hectares of land disturbed by mining operations, of which a total of 1,100 plots or $8,871.18$ hectares need to be rehabilitated. Ecological restoration, when implemented effectively and sustainably, contributes to protecting soil and biodiversity, improving human health and wellbeing, increasing food and water security, and economic prosperity; and supporting climate change mitigation, resilience, and adaptation (Gann et al. 2019).

Seed selection for restoring plant communities is a crucial issue. The most commonly used strategy is to use native plants in the area: since native species are well adapted to the local environment, they provide the best rehabilitation results. However, the evidence for local adaptation of species varies depending on the experimental method (Bucharova et al. 2017).

Native plants are widely used for biological rehabilitation but their growth, success and sustainable survival depend on when and how the seeds are harvested, and in what condition they are stored. Local plants have a genotype that is adapted to their environment, which provides a variety of advantages, while non-native plant genotypes are more likely to be unable to adapt to the new environment. Furthermore, intraspecific hybridization of local and non-local genotypes may have a negative impact on the genetic structure of local populations via mechanisms such as outbreeding depression (Vander Mijnsbrugge et al. 2010).

The unprecedented decision to use only native species for rehabilitation in OT-affected areas was a challenge as little research had previously been done on how to grow native Gobi Desert plant species and use them in rehabilitation efforts. This knowledge gap led to the creation of the OT Native Plant Propagation Center (NPPC) in Khanbogd Soum, which is tasked to conduct research on the collection of seeds, propagation of plants, and preparing seeds and saplings for restoration work (Oyu Tolgoi LLC, 2011). By starting rehabilitation programs early (during the construction stage), OT has had time to develop and test rehabilitation methods and to begin rehabilitation of areas to facilitate the establishment and growth of plants. Between 2012 and 2020, 34 native species were propagated from seed and two from cuttings and $>200,000$ saplings have been planted in rehabilitation areas (Oyu Tolgoi LLC, 2020). These saplings will be used at the age of 2-4 years to rehabilitate the area disturbed by the mine operation, and the success of the rehabilitation will be assessed by post-rehabilitation monitoring.

This paper aims to study the effectiveness of biological (re-vegetation) rehabilitation methods four years after rehabilitation attempts have been made in disturbed land of the cold arid desert. As a result, this work reports several important findings which will be of great interest for readers in the area of mine process, ecological system, rehabilitation and plant species. 


\section{Methodology}

\subsection{Study area}

The study was conducted in Khanbogd soum, Umnugovi aimag which is typical of Dalanzadgad subzone of Middle and South Gobi region, while in terms of natural zones and zonation it belongs to the Gobi Desert zone (Khaulenbek, 2014).

According to the classification of phyto-geographical regions of Mongolia, the study area belongs to the Dornod Gobi Desert steppe and Alashaa Gobi of Mongolia (Yunatov, 1977). Therefore, desert steppe edificator plants such as Eurotia ceratoides, Brachanthemum gobicum, Potaninia mongolica and Sympegma regelii and some sub-shrubs that reflect the basic appearance of the desert, such as Anabasis brevifolia and Salsola passerina are dominated (Yunatov, 1977; Balt, 2011; Indree, 2014). This area has more ancient endemic species than any other natural zones in Mongolia (Badarch et al. 2009).

In terms of climate, the soum is located in the arid warm summer zone and cold winter (Mongolian Academy of Sciences, 1990, p.17). According to the Khanbogd weather station's data for the last 44 years, the long-term mean temperature is around $7.5^{\circ} \mathrm{C}$ while the long-term mean precipitation is approximately $96.7 \mathrm{~mm}$. In 2017 and 2018 , the annual mean temperature was warmer by $1.6^{\circ} \mathrm{C}$ and $0.5{ }^{\circ} \mathrm{C}$, respectively, than the long-term mean temperature. In terms of precipitation, the precipitation in 2017 was $22.6 \mathrm{~mm}$ less than the long-term total mean precipitation, and that in 2018 was $76.1 \mathrm{~mm}$ more or 1.8 times higher than the long-term average. Rainfall pattern is partial in the Gobi region, and according to the Oyu Tolgoi meteorological station, the total precipitation in 2018 was $218.11 \mathrm{~mm}$, which is $121.11 \mathrm{~mm}$ more or 2.2 times higher than the long-term mean precipitation (Oyu tolgoi, 2018).

One of the highlights of the Khanbogd station's long-term data is that three cases of total annual precipitation of more than $170 \mathrm{~mm}$ have been reported. This was in 2003, 2010 and 2018, with $194.0 \mathrm{~mm}$, $173.0 \mathrm{~mm}$ and $172.8 \mathrm{~mm}$ of precipitation, respectively. However, if we look at the monthly distribution of precipitation in the first two years, the highest amount was in May, and in 2018, the highest amount was in July-August.

\subsection{Study site}

Total six sites were selected for the study, including three sites disturbed by OT construction period and rehabilitated in 2013, and three adjacent undisturbed areas as controls. Three main methods were used to rehabilitate these areas through sapling planting, drill seeding and hydroseeding. Figure 1 illustrates the site locations selected in Khanbogd soum, Mongolia in this study.

- Nariin Zag site is located $63.7 \mathrm{~km}$ northeast of the Oyu Tolgoi mine $\left(43^{\circ} 25^{\prime} 3.71^{\prime \prime} \mathrm{N}\right.$, $107^{\circ} 24^{\prime} 56.65^{\prime \prime}$, elevation $980.2 \mathrm{~m}$ ), which is located at the lowest elevation among the three monitoring plots. Five cluster boreholes are planned at Gunii Khooloi area to be used as a source of water for the Oyu Tolgoi copper-gold mine operation and its construction phase began in 2011. According to the pre-disturbance vegetation surveys, an average of 23 saxaul individuals were growing per hectare around CTP\#1 and CTP\#2, Gunii Khooloi. The saxaul forest is named Nariin Zag, which is located on terrace, with stand structure of $2 \%$ seedlings, $13 \%$ juvenile, $35 \%$ middleaged, $40 \%$ old saxaul, and $10 \%$ stump saxaul. In order to bring the biological rehabilitation work closer to its original state, saxaul saplings propagated by seed at Native Plant Propagation Center, Oyu Tolgoi LLC, were planted in the fall of 2013. The first area, 6.62 hectares, was planted with 10,677 saxaul saplings and in the spring of 2014, and the growth rate was $79.7 \%$ (Balt et al. 2018).

- Khanbumbat site is located $10.7 \mathrm{~km}$ north of the Oyu Tolgoi mine near Khanbumbat Airport $\left(43^{\circ}\right.$ $8^{\prime} 29.66$ "N, $106^{\circ} 50^{\prime} 30.67^{\prime \prime}$ E, elevation $1196.0 \mathrm{~m}$ ). The construction phase of Khanbumbat airport was completed in 2013, and a total of 130.1 hectares fenced including paved runway and other facilities. Outside area of the fence was technically rehabilitated as levelling, topsoil laying and deep ripping were carried out right after the construction phase. After that, seeds of four species 
(Anabasis brevifolia, Reaumuria soongorica, Eurotia ceratoides, and Salsola passerina) were planted in 24.6 ha by rate of $25 \mathrm{~kg} / \mathrm{ha}$ through drill seeding method.

- BP-KB1 site is located $32.7 \mathrm{~km}$ northeast of the Oyu Tolgoi mine and $2 \mathrm{~km}$ west of Khanbogd soum along the OT-Khanbogd unpaved road ( $43^{\circ} 11^{\prime} 53.62$ "N, $107^{\circ} 9^{\prime} 59.18^{\prime \prime}$ E, elevation $\left.1125.9 \mathrm{~m}\right)$. The 0.428 ha quarry used materials to improve the unpaved road in 2006 and was technically rehabilitated in late 2007. Due to the lack of previously stripped topsoil for technical rehabilitation, the quarry edge is sloped to resemble the condition of the area. In 2013, seeds of four species of Anabasis brevifolia, Reaumuria soongorica, Eurotia ceratoides, and Salsola passerina were used for biological rehabilitation at a rate of $25 \mathrm{~kg} / \mathrm{ha}$ through hydroseeding method.

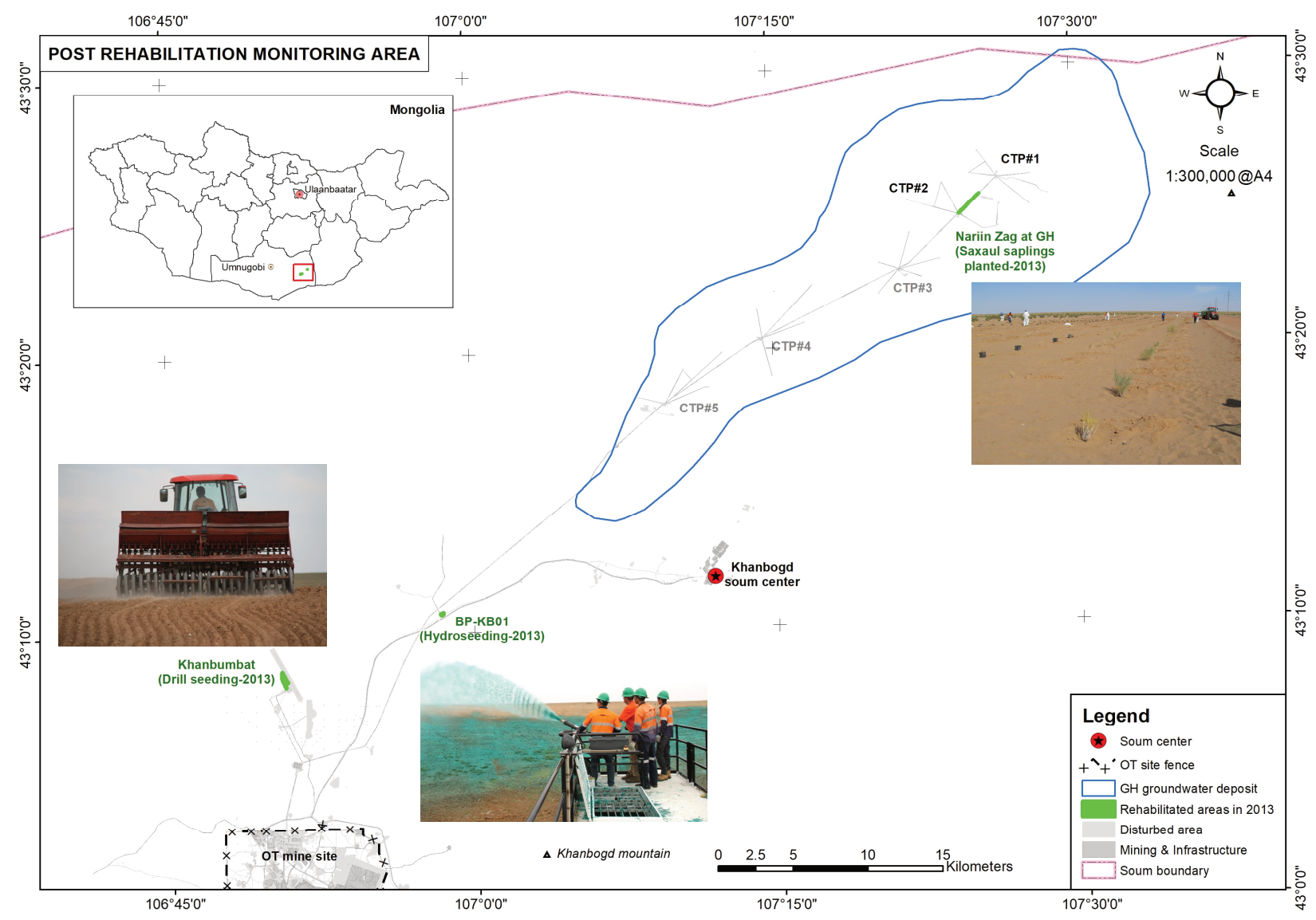

Figure 1 Locations of study sites in Khanbogd soum, Mongolia

\subsection{Method}

A plot of $30 \mathrm{~m}$ by $30 \mathrm{~m}$ was established at each site (see Figure 2). Four parallel transect lines with $30 \mathrm{~m}$ in length and spaced by $10 \mathrm{~m}$ in between were also established, starting from the upper left corner of each plot. 


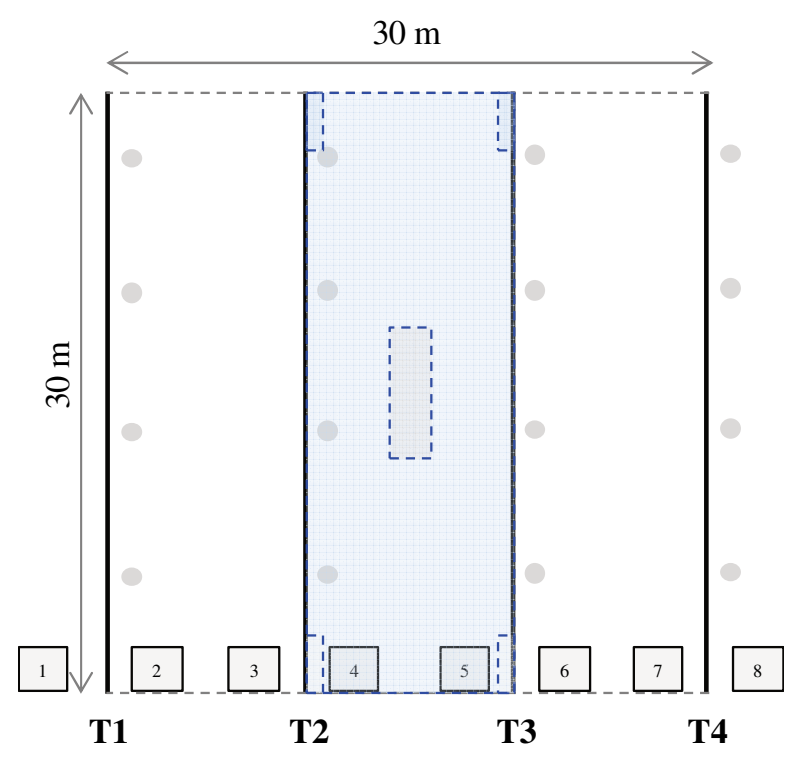

Figure 2 Schematic representation of survey for vegetation, soil and basal cover characterization (black line: transect lines for line-point intercept surveys and basal cover estimation, grey quadrats: quadrats for plant biomass sampling, blue dashed areas: areas for identification of dominant species, grey dots: areas for soil sampling).

\subsubsection{Species richness and density:}

Biological diversity is an estimate achieved by counting all species in samples and by weighing each species by their relative abundance. Sampling was undertaken in $30 \mathrm{~m} \times 10 \mathrm{~m}$ areas which were created by two transects in the middle (Figure 2). Plots $(2 \mathrm{~m} \times 5 \mathrm{~m}$ ) were established in the central area and four $0.5 \mathrm{~m} \times 2$ $\mathrm{m}$ plots were established in the corners of the $30 \mathrm{~m} \times 10 \mathrm{~m}$ areas. Counts of plant species and individuals in each of these areas were done for species richness estimation. Densities were calculated by counting the number of individuals of perennial species in the above areas.

\subsubsection{Vegetation cover:}

Line-point intercept methodology (Evans et al. 1933) is a fast, simple and effective way for identifying soil surface cover and species diversity that is quantitative and free from bias. In the line-point intercept, we recorded plant species that touched the pointer (a straight piece of wire or rod, such as a long pin flag, at least $75 \mathrm{~cm}$ long and $1 \mathrm{~mm}$ or less in diameter) every $25 \mathrm{~cm}$ along the line.

\subsubsection{Plant biomass:}

Biomass samples were collected for each species in an area of $1 \mathrm{~m} 2$ that is located at a distance of $1 \mathrm{~m}$ from each of the four lines (Figure 2). Samples taken from the field were dried in an oven (BOV-T30C-Biobase) at $70^{\circ} \mathrm{C}$ for $48 \mathrm{~h}$ and the dry biomass was weighed using an electronic scale.

\subsection{Analysis}

All data were entered into the DIMA database software (Courtright \& Van Zee, 2011) for final analysis and data were subjected to Jaccard coefficient using the statistical software EstimateS. 


\subsubsection{Similarity between plant communities}

Similarities of species composition of two communities are measured by the Jaccard coefficient. A general form of the Jaccard similarity coefficient is $S_{i}=\mathrm{c} / \mathrm{t}$

where:

$$
\begin{aligned}
& \mathrm{c}=\text { number of common species present in both communities } \\
& \mathrm{t}=\text { total number of species in the two communities compared. }
\end{aligned}
$$

$t$-test analysis was performed using JMP 10 software.

\section{$3 \quad$ Results}

\subsection{Sapling planting}

Plant cover and biomass in rehabilitated areas increased in 2018, but there was no significant difference between control vs rehabilitated area (plant cover: $\mathrm{t}=-0.88, \mathrm{p}=0.40$; plant biomass: $\mathrm{t}=-0.22, \mathrm{p}=0.83$ ) (Table 1). The cover and biomass of Haloxylon ammodendron remained to be high in the two consecutive years in the rehabilitated area. The Jaccard similarity coefficient between the control and rehabilitated area was $11.1 \%$ in 2017 , which significantly increased to $75 \%$ in 2018 (Figure 3). In the rehabilitated area, seven species were recorded in 2017 and also seven species in 2018. Of these seven species in 2018, four were annuals. Haloxylon ammodendron had a high density in the rehabilitated area in two consecutive years.
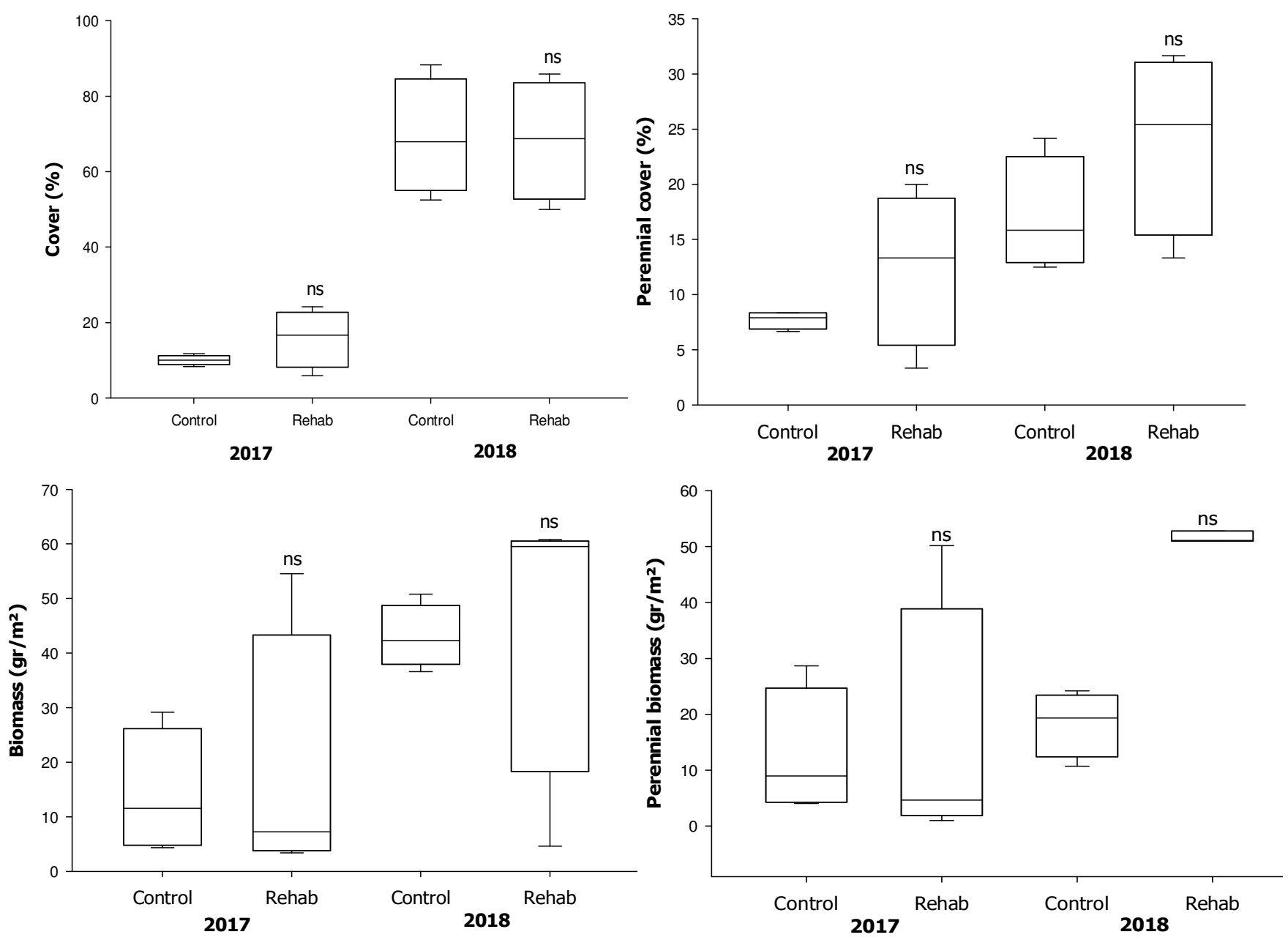

Figure 3 Plant cover and biomass in sapling planted area in comparison to the background control (ns-P $>0.05 ;{ }^{*} \mathrm{P} \leq 0.05 ;^{* *} \mathrm{P} \leq 0.01 ;{ }^{* * *} \mathrm{P} \leq 0.001 ;{ }^{* * *} \mathrm{P} \leq 0.0001$ ) 
Vegetation in the study area is divided into annuals and perennials. This shows that perennial cover is high in the area planted with Haloxylon ammodendron seedlings. Annual vegetation cover increased sharply in 2018. Among the annuals, Eragrostis minor and Aristida Heymannii had the highest vegetation cover. Biomass is similar to the vegetation cover trend (Table 1).

Table 1 Comparison of vegetation cover by plant life-form and year

\begin{tabular}{l|lllll}
\hline \multicolumn{1}{c}{} & & $\mathbf{2 0 1 7}$ & \multicolumn{3}{c}{$\mathbf{2 0 1 8}$} \\
\hline \multirow{3}{*}{ Cover } & Control & Perennial & Annual & Perennial & Annual \\
& Rehab & 13.75 & 4.62 & 20 & 63 \\
\multirow{2}{*}{ Biomass } & Control & 42.07 & 5.12 & 28.75 & 53.25 \\
& Rehab & 52.6 & 5.68 & 25.32 & 26.90 \\
& & & 5.66 & 51.63 & 8.09 \\
\hline
\end{tabular}

\subsection{Drill seeding}

In 2018, the plant cover in the rehabilitated area $(t=15.27, p=0.0001)$ and biomass were higher than previous year, but there was no significant difference between control and rehabilitated area ( $t=-0.44$, $p=0.67$ ) (Figure 4). At the species level, the cover of Halogeton glomeratus, an annual plant species, was highest in the rehabilitated area. Moreover, the biomass of Halogeton glomeratus showed the highest level among all other species recorded in the rehabilitated area, as well as in control area. In 2018, the biomass of Anabasis brevifolia increased while that of Salsola passerina decreased. Among the recorded species in the control area in 2018, Kochia melanoptera was highest in biomass. The Jaccard similarity coefficient was $0 \%$ in 2017 and 2018 between control vs rehabilitated area. In the rehabilitated area, there was one species recorded in 2017 and six in 2018, with all six species being annuals. Two perennial plants, namely Cleistogenes songorica and Ptilotrichum canescens, were recorded with very low density in the rehabilitated area in 2017, while no perennial plant was recorded in 2018.

No perennial vegetation data were recorded in the drill seeded area. The annual plant Halogeton glomeratus had the highest coverage of any species, and in 2018 its coverage increased dramatically. In 2017, Convolvulus Ammanii weighed 0.15 grams per square meter of biomass sample, and in 2018, one species of Reaumuria soongorica biomass was recorded (Table 2).

Table 2 Comparison of vegetation cover by plant life-form and year

\begin{tabular}{llllll}
\hline & \multicolumn{3}{c}{$\mathbf{2 0 1 7}$} & \multicolumn{3}{c}{$\mathbf{2 0 1 8}$} \\
\hline \multirow{3}{*}{ Cover } & & Perennial & Annual & Perennial & Annual \\
& Control & 8.12 & 0.20 & 3.13 & 18.19 \\
\multirow{3}{*}{ Biomass } & Rehab & 0 & 0.20 & 0 & 44.79 \\
& Control & 26.81 & 0.36 & 15.428 & 46.65 \\
& Rehab & 0.15 & 14.38 & 7.094 & 59.64 \\
\hline
\end{tabular}



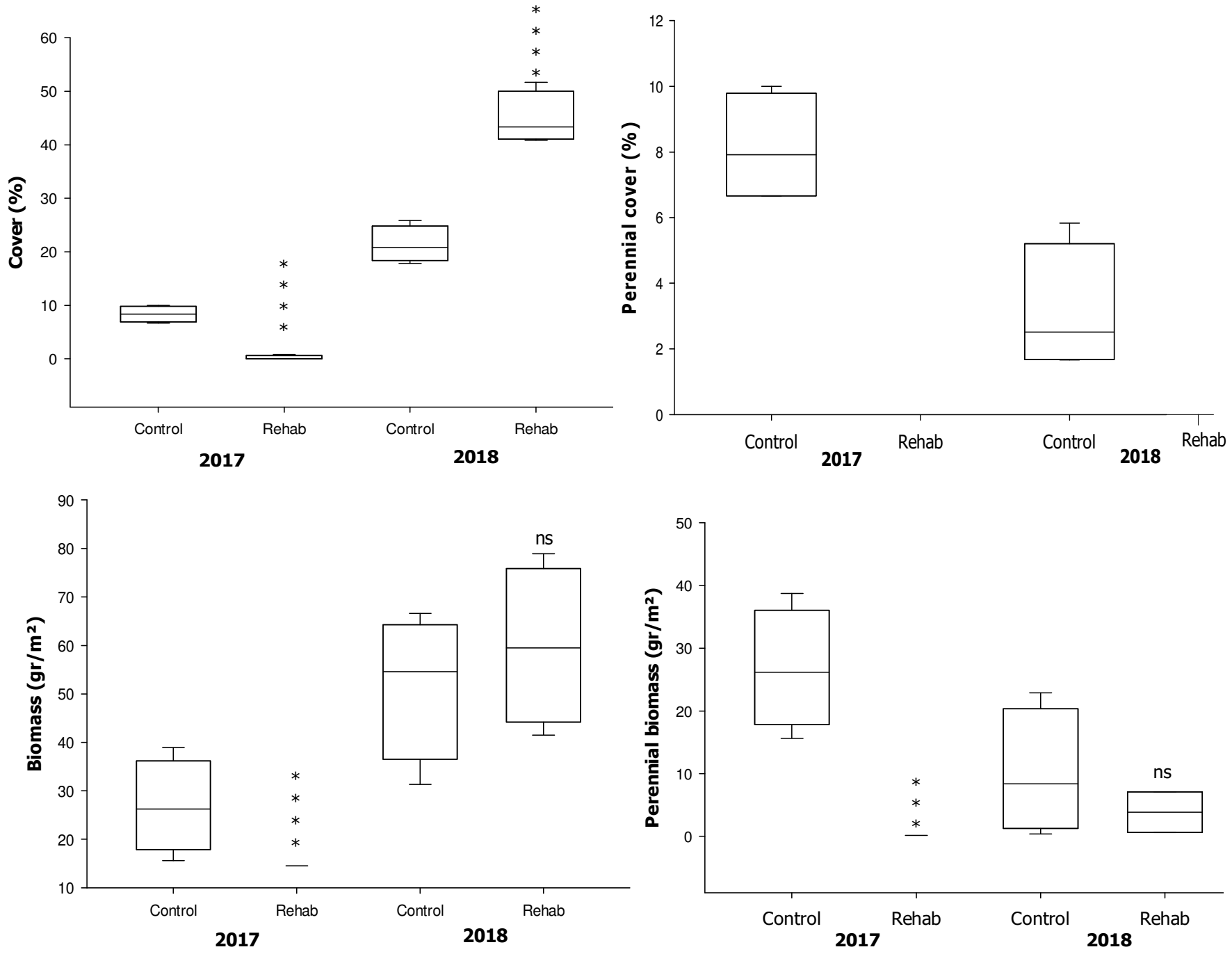

Figure 4 Plant cover and biomass in drill seeded area in comparision to its control (ns-P > 0.05; * $\mathrm{P} \leq$ $0.05 ;{ }^{* *} P \leq 0.01 ;{ }^{* * *} P \leq 0.001 ;{ }^{* * * *} P \leq 0.0001$ ).

\subsection{Hydroseeding}

In the rehabilitated area, the plant cover increased in 2018, while the plant biomass decreased from the previous year (Figure 5). The Jaccard similarity coefficient between the control and rehabilitated area was $27.3 \%$ in 2017 and $45.5 \%$ in 2018. There were 10 plant species recorded in 2017 for the rehabilitated area while 9 species were recorded in 2018. Six of these nine species were annual plants (In 2018, the perennial vegetation cover and biomass of the wet plowing area decreased. However, the annual vegetation cover has increased sharply. Chloris virgata was the highest annual cover in 2018, while Aristida Heymannii had the highest coverage in 2017. From perennials, Anabasis brevifolia biomass and cover decreased slightly from 2017, which was the main reason for the decrease in perennial cover and biomass. Biomass of perennial plants such as Cleistogenes songorica and Stipa gobica, which were recorded in 2017, were not recorded in 2018 (Table 3).

Table 3). In 2017, Anabasis brevifolia was abundant in the rehabilitated area among the perennial plants planted and plants that constituted the community. In 2018, yet still making up the only perennial species recorded this year. In the control site, species such as Stipa gobica and Eurotia ceratoides occurred with high density but they decreased in 2018. Among the annual plants recorded in the rehabilitated area, Bassia dasyphylla and Halogeton glomeratus were most abundant. 

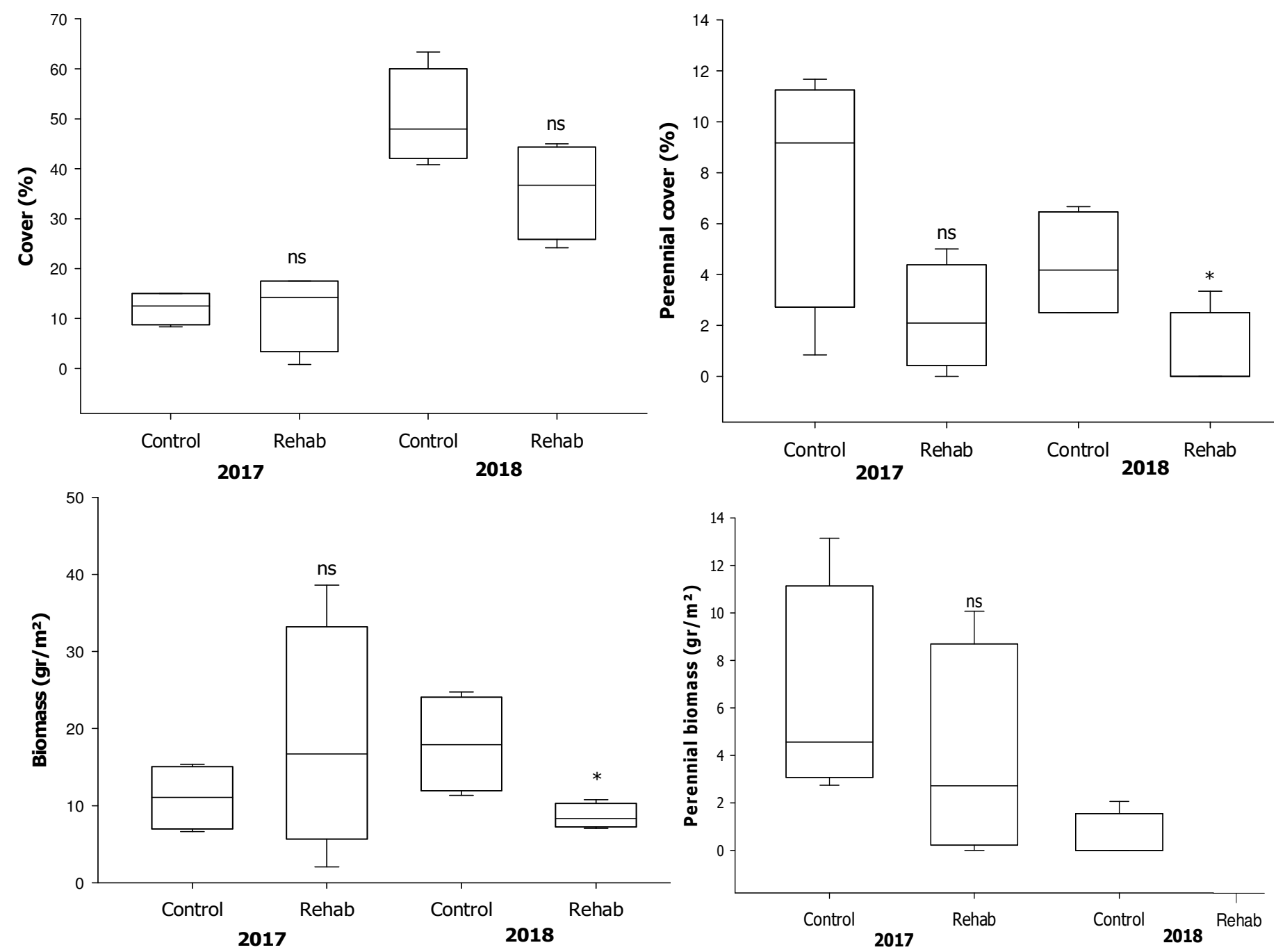

Figure 5 Plant cover and biomass in hydroseeded area in comparison to its control (ns-P > 0.05; $P \leq$ $0.05 ; * * P \leq 0.01 ;{ }^{* * *} P \leq 0.001 ;{ }^{* * * *} P \leq 0.0001$ ).

In 2018, the perennial vegetation cover and biomass of the wet plowing area decreased. However, the annual vegetation cover has increased sharply. Chloris virgata was the highest annual cover in 2018, while Aristida Heymannii had the highest coverage in 2017. From perennials, Anabasis brevifolia biomass and cover decreased slightly from 2017, which was the main reason for the decrease in perennial cover and biomass. Biomass of perennial plants such as Cleistogenes songorica and Stipa gobica, which were recorded in 2017, were not recorded in 2018 (Table 3).

Table 3 Comparison of vegetation cover by plant life-form and year

\begin{tabular}{llllll}
\hline \multicolumn{5}{c}{ Cover } & \multicolumn{3}{c}{$\mathbf{2 0 1 7}$} & \multicolumn{3}{c}{$\mathbf{2 0 1 8}$} \\
\hline \multirow{4}{*}{ Biomass } & Perennial & Annual & Perennial & Annual \\
& Control & 8.25 & 5.875 & 6 & 53.25 \\
& Rehab & 2.5 & 11.12 & 0.75 & 42 \\
& Control & 29.6 & 2.15 & 9.7 & 14.77 \\
& Rehab & 17.36 & 13.39 & 2.06 & 8.95 \\
\hline
\end{tabular}




\section{Discussion}

Many methods of rehabilitation have been developed andmuch efforts have been made in the plant transplantation, but their success has been variable and mostly difficult to assess (Kiehl et al. 2010). An observation in the United Kingdom found that 18 saplings reached $54-91 \%$ cover after 3-7 years after transplanting (Bullock et al. 1998). Pywell (2007) and Walker (2004) pointed out that microenvironment is more important than species richness, species composition, and seed content for the success of rehabilitation. Many scientists agree that it is important to prepare the site in advance (Pywell et al. 2007). It has also been observed that the formation of rich pastures depends on the distribution of seeds, fertile soils and plant-derived raw materials (Kiehl et al. 2010). In addition, differences in mycorrhizal fungi in the soil affect the plant adaptation (Pankova et al. 2008). Basic reclamation studies were conducted before mining began, but ecosystem rehabilitation is more likely to occur after the mining operations (Boyer et al. 2010). In arid and semi-arid climates, shrubs and woody plants create a strong natural system that prevents soil erosion for a long time, creating a habitat that preserves species diversity and functional diversity. Shrubs and trees also increase nutrients in other plant growing environments, reduce stress due to lack of moisture, and improve soil physical properties (Belsky et al. 1989; Tiedemann and Klemmedson 1973, 2004).

The main requirement of the Government of Mongolia for biological rehabilitation is to bring it closer to the original vegetation cover of the area that is being rehabilitated. For this purpose, the plant species selected for rehabilitation should be commensurate with the richness, stand biomass, and cover of the vegetation within the radius of $50 \mathrm{~km}$. Basic requirements for rehabilitation are vegetation cover of the rehabilitated area which has reached $60 \%$ of the local vegetation cover; and the plant species composition of the rehabilitated area has reached $30 \%$ of the species composition of the nearby undisturbed area. The proportion of annual and biennial plant cover of the rehabilitated area shall be determined as up to $25 \%$ in steppe and Gobi regions. Results from our study confirm that drill seeded area did not meet the Mongolian government criteria of plant cover in 2017. However, the same drill seeded area met the criteria for plant cover in 2018 in response to the rainfall that led to increased growth and establishment of the annual species. This has shown a major impact on increase of the plant cover. Sapling planted area achieved the criteria of plant cover and richness. In some areas, the annual plant cover exceeded the criteria in 2018 in sapling planted areas.

The results supported the importance of plant establishment and growth on rehabilitation areas which assists in the stability of the communities. However, rehabilitation with saplings should be carried out by experienced technicians in accordance with the appropriate technology, which is considered to have a significant impact on the effectiveness of this method. Long-term monitoring of the rehabilitation areas will assist in continuous improvement in techniques and outcomes of ecosystem rehabilitation in this arid Gobi desert region. Furthermore, poor vegetation performance in drill seeded area possibly related to seed germination, as seed quality is an important factor in increasing vegetation productivity. In this regard, it is necessary to conduct experiments on the technology of drill seed method and seed quality studies.

\section{Conclusion}

The preliminary results of the vegetation study show that the method for sapling planting is more effective than the other methods in the Gobi desert area. For hydroseeded area, all of seeded plants grew in rehabilitated area in 2017 but all plants did not grow except Anabasis brevifolia in 2018. Haloxylon ammodendron in sapling planted area was recorded in two consecutive years.

\section{Acknowledgement}

The study was funded by Oyu Tolgoi LLC. Thanks to the staff of the Ecological-Evolutionary Synthesis Laboratory of the National University of Mongolia, who supported the input of field research data into the database, O.Tseesuren, who provided historical data and knowledge of rehabilitated area, N.Purevsuren, 
who prepared the map, Sh.Uranchimeg and D.Bataa, who provided support on weather information and Sh.Anarmaa and T.Samdanjigmed, who provided general support to write this article.

\section{References}

Badarch, M, Dorjgotov, B \& Enkhbat, A 2009, Mongolian's fourth national report on implementation of convention of biological diversity. http://www.Cbd.Int/Doc/World/Mn/Mn-Nr-04-En.Pdf, 70, 94-110.

Balt, A, Batsuuri, D \& Purevsuren, U 2018, Rehabilitation handover report of Nariin Zag forest, Khanbogd soum, SouthGobi province. Oyu Tolgoi LLC.

Balt, A 2011, Vegetation pattern and environmental factors in Semi-Desert and Desert Areas of Mongolia : Case Study in Khanbogd Soum. 26.

Belsky, AJ, Amundson, RG, Duxbury, JM, Riha, SJ, Ali, AR \& Mwonga, SM 1989, 'The effects of trees on their physical, chemical, and biological environments in a semi-arid savanna in Kenya'. Journal of Applied Ecology, vol. 26, pp. 1005-1024.

Boyer, S \& Wratten, SD 2010, 'The potential of earthworm to restore ecosystem services after opencast mining-A review'. Basic Applied Ecology, vol. 11, pp. 196-203.

Bucharova, A, Durka, W, Hölzel, N, Kollmann, J, Michalski, S \& Bossdorf, O 2017, 'Are local plants the best for ecosystem restoration? It depends on how you analyze the data'. Ecology and Evolution, vol. 7, no. 24, pp. $10683-10689$. https://doi.org/10.1002/ece3.3585

Bullock, JM 1998, 'Community translocation in Britain: Setting objectives and measuring consequences'. Biological Conservation, vol. 84, pp. 199-214.

Courtright, EM \& Van Zee, JW 2011, 'The database for inventory, monitoring, and assessment (DIMA)'. Rangelands, vol. 33, no. 4, pp. 21-26. https://doi.org/10.2111/1551-501X-33.4.21

Gann, GD, McDonald, T, Walder, B, Aronson, J, Nelson, CR, Jonson, J, Hallett, JG, ... Dixon, KW 2019, 'International principles and standards for the practice of ecological restoration. Second edition'. Restoration Ecology, vol. 27, no. S1, pp. S1-S46. https://doi.org/10.1111/rec.13035

Indree, Т 2014, Монгол орны хээрийн ургамалжилт [The steppe vegetation of Mongolia]. Bembi san. https://www.researchgate.net/publication/271447701_The_Steppe_Vegetation_of_Mongolia

Khaulenbek, A 2014, Location of Gobi oases in South Gobi; current status and potential for rehabilitation in Gobi oases (Report). Institute of Geography and Geoecology.

Kiehl, K, Kirmer, A, Donath, TW, Rasran, L \& H€olzel, N 2010, 'Species introduction in restoration projects - evaluation of different techniques for the establishment of semi-natural grasslands in Central and Northwestern Europe'. Basic and Applied Ecology, vol. 11, pp. 285-299.

Mineral Resources and Petroleum Authority of Mongolia 2021, Mineral resources and petroleum statistic's report.

Mongolian Academy of Sciences 1990, National atlas of Mongolia.

Oyu Tolgoi LLC. 2011, Report on the implementation of the environmental protection plan. https://www.ot.mn/ /reports/Environment/

Oyu Tolgoi LLC. 2018, Report on the implementation of the environmental protection plan. https://www.ot.mn/ /reports/Environment/

Oyu Tolgoi LLC. 2020, Report on the implementation of the environmental protection plan. https://www.ot.mn/ /reports/Environment/

Pankova, H, Munzbergova, Z, Rydlova, J \& Vosatka, M 2008, 'Differences in AM fungal root colonization between population of perennial Aster species have genetic reasons'. Oecologia, vol. 157, pp. 211-220.

Pywell, RF, Bullock, JM, Tallowin, JB, Walker, KJ, Warman, EA \& Masters, G 2007, 'Enhancing diversity of species-poor grassland: An experimental assessment of multiple constraints'. Journal of Applied Ecology, vol. 44, pp. 81-94.

Yunatov, AA 1977, Бүгд Найрамдах Монгол Ард Улсын ургамлан нөмрөгийн үндсэн шинжүүд [Основные черты растительного покрова Монгольской Народной Республики]. State Publication House, Ulaanbaatar.

Tiedemann, AR \& Klemmedson, JO 1973, 'Nutrient availability in desert grassland soils under mesquite (Prosopis juliflora) trees and adjacent open areas'. Soil Science Society of America, vol. 37, pp. 107-11.

Tiedemann, AR \& Klemmedson, JO 2004. 'Responses of desert grassland vegetation to mesquite removal and regrowth'. Journal Range Management, vol. 57, pp. 455-465.

Vander Mijnsbrugge, K, Bischoff, A \& Smith, B 2010, 'A question of origin: Where and how to collect seed for ecological restoration'. Basic and Applied Ecology, vol. 11, no. 4, pp. 300-311. https://doi.org/10.1016/j.baae.2009.09.002

Veste, M, Littmann, T, Friedrich, H \& Breckle, SW 2001, 'Microclimatic boundary conditions for activity of soil lichen crusts in sand dunes of the north-western Negev desert, Israel'. Flora, vol. 196, no. 6, pp. 465-474.

Walker, KJ, Stevens, PA, Stevens, DP, Mountford, JO, Manchester, SJ \& Pywell, RF 2004, 'There storation and re-creation of species rich lowland grassland on land formerly managed for intensive agriculture in the UK'. Biological Conservation, vol. 119, pp. $1-18$.

Wesche, K \& Treiber, J 2012 'Abiotic and biotic determinants of steppe productivity and performance-a view from Central Asia'. in MJA Werger \& MA van Staalduinen (eds.) Eurasian steppes. Ecological problems and livelihoods in a changing world, Springer, Dordrecht. 